\title{
Cancer Stem Cells: Cell Culture, Markers and Targets for New Therapies
}

\author{
Candace A. Gilbert and Alonzo H. Ross \\ Department of Biochemistry and Molecular Pharmacology, University of Massachusetts Medical \\ School, Worcester, MA 01605
}

\begin{abstract}
A cancer stem cell is defined as an undifferentiated cell with the ability to self-renew, differentiate to multiple lineages and initiate tumors that mimic the parent tumor. In this review, we focus on glioblastomas, describing recent progress and problems in characterizing these cells. There have been advances in cancer stem cell culture, but tumor cell heterogeneity has made purification of cancer stem cells difficult. Indeed, it may be that cancer stem cells significantly vary from tumor to tumor. We also discuss the proposal that cancer stem cells are resistant to radiotherapy and chemotherapy and play a major role in repopulating tumors following treatment. To overcome their resistance to conventional therapies, we may be able to use our extensive knowledge of the signaling pathways essential for stem cells during development. These pathways have potential as targets for new glioblastoma therapies. Hence, although there is an ongoing debate on the nature of cancer stem cells, the theory continues to suggest new ideas for both the lab and the clinic.
\end{abstract}

\section{Keywords}

stem cell; brain tumor; tumor markers; cell culture

Tumors are heterogeneous, containing a relatively rare population of cancer stem cells (CSCs), while the majority of the cells are either transit-amplifying cells or differentiated cells (Fig. 1). A CSC is defined as an undifferentiated cell with the ability to self-renew, differentiate into multiple lineages and initiate tumors that mimic the parent tumor. Links between cancer and stem cells have been proposed for years, because many pathways that are altered in cancer cells regulate normal functions of embryonic and adult stem cells. However, it is unclear whether these CSCs are derived from adult stem cells, or if mutations in a progenitor or even a terminally differentiated cell lead to a tumor cell with stem cell characteristics. The presence of CSCs was first demonstrated in acute myeloid leukemia [Bonnet and Dick, 1997], and more recently in solid tumors, such as breast [Al-Hajj et al., 2003], prostate [Tang et al., 2007], colon [O'Brien et al., 2007], and brain [Singh et al., 2003; Singh et al., 2004]. Accumulating evidence suggests that CSCs play major roles in tumor initiation, angiogenesis, maintenance, and metastasis [Eyler and Rich, 2008]. CSCs are also clinically important because they are more resistant to radiation and chemotherapy treatments than the bulk tumor cells [Bao et al., 2006;Liu et al., 2006]. This resistance has been attributed to the quiescent phenotype and enhanced DNA repair in CSCs, as well as the expression of drug efflux pumps and anti-apoptotic proteins.

Correspondence to: Alonzo H. Ross, Department of Biochemistry and Molecular Pharmacology, 364 Plantation St., Room 819, Worcester, MA 01605 USA. 508-856-8016, FAX 508-856-2003, Alonzo.Ross@ umassmed.edu. 
In this review, we will focus on neural stem cells (NSC) and CSCs in glioblastoma multiforme (GBM). For many years, it was assumed that the brain contained mitotic cells only during early development. It is now known that neurogenesis persists throughout life, due to the presence of neural stem cells (NSCs). In the adult brain, NSCs are located primarily in the subventricular zone [Altman, 1963] and the dentate gyrus [Altman and Das, 1965]. NSCs and CSCs share many characteristics. Both cell types express stem cell markers, migrate through normal brain tissue and are capable of self-renewal. In addition, the heterogeneous composition of brain tumors, which can include multiple neural lineages, posits the presence of CSCs.

GBM is the most aggressive class of brain tumors. The current treatment is an intense, but only palliative, combination of surgical resection, radiotherapy, and chemotherapy. The standard chemotherapy drug is temozolomide (TMZ), an alkylating agent that is taken orally and readily penetrates the blood-brain barrier [Ostermann et al., 2004]. It is often given at low-doses concomitant with radiotherapy, followed by adjuvant standard doses. This aggressive treatment schedule results in an increase of the two-year survival rate from $10.4 \%$ with radiotherapy alone to $26.5 \%$ [Stupp et al., 2005]. Despite multimodality treatments and advances in chemotherapy regiments, the average time for recurrence of the tumor is only 6.9 months, and the five-year survival rate for GBM patients is still less than $5 \%$ [Stupp et al., 2009]. There is currently no cure for GBM, because the surgeon cannot effectively remove this diffuse tumor, and there is a small population of resistant cells that escapes radiotherapy- and chemotherapy-induced cell death. These cells can stay dormant for extended periods after treatment but eventually re-enter the cell cycle, leading to tumor re-growth. CSCs have been proposed to be these dormant cells and, thereby, to mediate tumor resistance and re-growth in multiple cancers [Eyler and Rich, 2008]. Targeting CSCs in combination with current therapies that kill the bulk of the tumor may enhance the patient's chance for long-term survival. As a result, development of treatments to target the CSC population is a priority.

In this Prospect, we will consider recent progress as well as persistent problems that arise in studying GBM CSCs. A critical aspect of CSC research is the ability to propagate cells that maintain the properties of both the stem cells and the original tumor. We will discuss the advantages and disadvantages for CSC research of serum cultures, serum-free neurosphere cultures and the recently described serum-free adherent cultures. We will also examine the current methods used to identify and isolate GBM CSCs using surface markers and side populations. A current research focus is whether GBM CSCs are truly the population resistant to therapy. If CSCs evade treatment, an important question is whether future therapeutics can be directed against CSCs. Promising data has revealed that inhibition of stem cell pathways in brain tumors, such as Notch and Hedgehog signaling, may present a novel means to directly target the resistant CSC population.

\section{EXPANDING THE CSC POPULATION}

In order to study glioma CSCs, the first requirement is to have a system, in which they can be propagated. When the CSC theory became relevant to glioma research, new methods to culture CSCs for multiple passages and expand the stem cell-like population came into existence. Here we will summarize the culture systems used for glioma CSCs, with their pros and cons (Table 1).

\section{NEUROSPHERE STEM CELL CULTURES VS. SERUM CULTURES}

GBM cells were traditionally grown in vitro as adherent cultures in the presence of serum. These cultures are tumorigenic; however, many are not invasive in xenograft models, in stark contrast to GBMs in patients. In serum, GBM cells express high levels of 
differentiation markers, suggesting that these cultures are not suitable for CSC research. In 1992 , it was discovered that NSCs could be expanded in defined, serum-free media supplemented with growth factors [Reynolds and Weiss, 1992]. At low densities, the NSCs grow as non-adherent clonal spheres, termed neurospheres. In 2003, Dirks and coworkers demonstrated that cells isolated from pediatric brain cancers and GBMs were able to form neurospheres in a similar serum-free media [Singh et al., 2003]. Neurospheres are heterogeneous aggregates derived from a single CSC or early progenitor cell. When dissociated, these cultures are capable of serial plating, in which a small percentage of the cells can form secondary and tertiary neurospheres for many passages [Reynolds and Weiss, 1996]. This demonstrates their high capacity for proliferation and self-renewal. A fraction of these cells are capable of multilineage differentiation into neuronal and glial lineages, and there are some abnormal cells with mixed phenotypes [Singh et al., 2003]. Treatment of NSCs and GBM neurospheres with serum leads to astroglial differentiation. Conversely, some adherent GBM lines derived in media containing serum, can be converted to neurospheres in serum-free media [Qiang et al., 2009].

Neurosphere cultures derived from primary tumors express known NSC genes, such as Musashi-1 (Msi-1), Sox2, and Bmi-1 [Hemmati et al., 2003](Fig. 1). Serum-free media cultures recapitulate the original tumor gene expression profile more accurately than serum cultures [Lee et al., 2006]. Additionally, in intracerebral xenograft models, neurosphere cultures form invasive tumors [Singh et al., 2004] The neurosphere cultures are an excellent model to study CSCs, since they expand the population of cells with NSC-related genes and have fewer genetic alterations than serum cultures. Depending on the cell line, the percentage of CSCs varies from 1-30\%, as judged by the capacity to form neurospheres. The majority of cells in a neurosphere are believed to be more differentiated transitamplifying cells [Ahmed, 2009]. After extended periods of serum-free culture (>20 passages), we have observed that the morphology of neurospheres changes from densely packed spheres with almost indiscernible individual cells to more loosely packed spheres. The rate of neurosphere formation is also increased at higher passages. Other labs have confirmed this and demonstrated morphology and growth rate changes after 4 months of neurosphere culture, suggesting that although serum-free cultures are a better in vitro system than serum cultures, neurosphere tumor cells also change with time in culture [Zhang et al., 2006]. In addition, the neurosphere assay is a fastidious assay. Even the time between dissociation of spheres affects the reproducibility of the results. While splitting spheres too early can result in an increase in the percentage of neurosphere-initiating cells, waiting too long to dissociate spheres increases the likelihood of cell death. Also, neurospheres aggregate and fuse with one another when plated at higher densities [Singec et al., 2006]. Therefore, the number of neurospheres is a measure of the number of CSCs, only if the cells are plated at low-densities. Despite these concerns, neurosphere cultures remain a valuable tool in GBM CSC research.

There are several methods of neurosphere dissociation. The most common means of obtaining single cell suspensions is mechanical dissociation pipetting. Enzymatic dissociation is also used, but proteases can cleave cell surface markers, such as CD133, and therefore, result in an underestimation of the percentage of CSCs and ineffective sorting. Our lab has had greater success in maintaining primary cultures through multiple passages when neurospheres are dissociated by brief exposure to a strong alkaline solution and gentle trituration [Sen et al., 2004]. This pH dissociation method is less harsh on the cells than traditional mechanical dissociation and does not affect the stem cell properties of the culture.

\section{THE NEXT GENERATION STEM CELL CULTURE}

A key aspect of the neurosphere culture system is that the defined, serum-free media allow for expansion of CSCs; however, the structure of the neurosphere is problematic for 
research. The presence of differentiated progeny and necrosis within the neurospheres, is believed to be due to the dense cell packing, which inhibits the diffusion of the growth factors to the innermost cells [Woolard and Fine, 2009]. A new approach to expand glioma cultures with a high percentage of CSCs has recently been described [Pollard et al., 2009]. Cells obtained from human glioma samples can be grown as adherent cultures on laminincoated cell culture plates in the same serum-free medium used for neurosphere cultures. The monolayer adherent culture allows all cells equal access to growth factors, which impedes differentiation and apoptosis. These adherent glioma CSC lines were less heterogeneous than neurosphere cultures, and almost all cells expressed CSC genes, such as Sox2, Nestin, CD133 and CD44 (Fig. 1). Very few of these cells expressed differentiation markers. In addition, the adherent cultures formed tumors when only 100 cells were intracranially injected into immunocompromised mice. Pollard et al. also found that the adherent CSC cultures are a superior system for high-throughput drug screens, and they were able to produce adherent cell lines from all examined glioma tissues with good cell viability. This new method for expanding a more homogeneous population of CSCs has significant advantages and will receive a great deal of attention.

\section{IDENTIFYING CSCs}

Markers are commonly used to identify and isolate different cells types. A break-through for studying NSCs came with the discovery of surface markers that could be used to sort cells by fluorescence-activated cell sorting or magnetic bead isolation. Leukemias currently have one of the most accepted models of CSCs due to an excellent set of markers that elucidates the lineages of both normal hematopoietic and leukemia cells. An important direction for glioma research is to distinguish CSCs from their progeny. Several markers have been proposed for glioma CSCs. Nestin, an intermediate filament protein, is expressed in NSCs and was the first widely used neural stem cell marker [Lendahl et al., 1990]. Unfortunately, nestin is a cytoplasmic protein, which makes it unhelpful as a means for sorting the CSC population. There is currently no universally accepted collection of CSC markers for isolation of a pure population of GBM stem cell-like cells. Here we will review the most commonly used glioma stem cell markers, CD133, A2B5 and. SSEA-1.

CD133 (Prominin-1) is a surface marker for NSCs [Uchida et al., 2000] and is used to isolate populations of CSCs with enhanced stem cell phenotypes from multiple types of brain cancer [Singh et al., 2003; Singh et al., 2004]. CD133 was first used as a marker for hematopoietic stem cells [Miraglia et al., 1997]. CD133 ${ }^{+}$cells from GBMs are capable of multilineage differentiation and have a high capacity for neurosphere formation. Furthermore, $\mathrm{CD} 133^{+}$cells isolated from GBMs express significantly higher levels of NSC genes [Liu et al., 2006], supporting the stem cell genotype of CD133 ${ }^{+}$CSCs and suggesting that similar signaling pathways may be involved in normal NSCs and brain cancers. CD133+ cells were shown to have elevated levels of the stem cell genes nestin, Msi-1, maternal embryonic leucine zipper kinase (MELK) and CXCR4. The gold standard to classify a cell as a CSC is that it can initiate a tumor that closely resembles the patient's tumor and is capable of serial transplantation. $\mathrm{CD} 133^{+} \mathrm{GBM}$ and medulloblastoma cells have an increased capacity for tumor initiation after intracranial transplantation into NOD-SCID mice [Singh et al., 2004]. Injection of only $100 \mathrm{CD} 133^{+}$cells results in tumors capable of serial transplantation, while $100,000 \mathrm{CD} 133^{-}$injected cells do not form tumors.

CD133 is a glycosylated transmembrane protein, and the antibodies commonly used for isolation, AC133 and AC141, are stated to be glycosylation-dependent [Bidlingmaier et al., 2008]; however, data documenting this is lacking. This is an important issue, because glycosylation status may be a key factor, affecting the use of CD133 as a CSC marker. In 
addition, discrepancies in other tissues have been found between the expression levels and distribution of CD133 based on protein expression and mRNA levels [Corbeil et al., 2000; Florek et al., 2005]. In the hematopoietic system, the proteins detected by the AC133 and AC141 antibodies appear to be differentially expressed [Green et al., 2000]. Since the relationship between these two antibodies has not been examined in GBMs, the use of these antibodies as the sole CSC markers is a concern.

Little is known about CD133 function, but recent reports demonstrate that its expression may be cell cycle- or proliferation-dependent [Beier et al., 2007; Jaksch et al., 2008]. In the prostate, CD133 may mark both the transit-amplifying population and the stem cells [Grey et al., 2009]. This data implies that CD133 may only be identifying subset of CSCs, and $\mathrm{CD} 133^{+}$populations may include progenitor cells. Reports that up to $40 \%$ of freshly isolated GBM tumors do not express CD133 [Beier et al., 2007] highlight the limits of selecting for GBM CSCs using CD133 [Son et al., 2009]. These CD133- tumors still demonstrate stem cell-like properties of self-renewal, multilineage differentiation, and xenograft tumor formation. Therefore, although CD133 is useful as a tool to isolate a population of cells with enhanced stem cell properties, it is not a universal stem cell marker for GBMs.

A2B5

A2B5 is a cell surface ganglioside that marks neural precursor cells in the adult human brain [Nunes et al., 2003]. Tchoghandijian et al, also demonstrated that a fraction of the NSCs isolated from human embryo subventricular zone are $\mathrm{A}_{2} \mathrm{~B}^{+}$. NSCs derived from human embryonic stem cells (hESCs) also demonstrate surface expression of A2B5 [Pruszak et al., 2007]. Recently, two labs reported that GBM cells recognized by the A2B5 monoclonal antibody have CSC properties [Ogden et al., 2008; Tchoghandjian et al., 2009]. A2B5 ${ }^{+}$cells are capable of intracranial tumor formation, while $\mathrm{A} 2 \mathrm{~B}^{-}$cells do not initiate tumors [Tchoghandjian et al., 2009]. Both the $\mathrm{A} 2 \mathrm{~B} 5^{+} / \mathrm{CD} 133^{+}$and the $\mathrm{A} 2 \mathrm{~B} 5^{+} / \mathrm{CD} 133^{-}$populations are capable of neurosphere formation and tumor initiation. These results suggest that A2B5 has promise as an additional CSC marker for gliomas.

\section{SSEA-1}

Stage-Specific Embryonic Antigen-1 (SSEA-1, CD15, Lewis-X Antigen) is a carbohydrate antigen associated with glycolipids and glycoproteins. SSEA-1 expression has been demonstrated on NSCs derived from human embryonic stem cells (hESCs), embryonic NSCs and GBM CSCs [Barraud et al., 2007; Pruszak et al., 2007; Son et al., 2009]. The SSEA- $1^{+}$cells have increased expression of stem cell genes, such as Sox 2 and Bmi1, and are capable of self-renewal and multilineage differentiation [Son et al., 2009]. SSEA- ${ }^{+}$cells isolated from GBMs are highly tumorigenic, while SSEA-1 ${ }^{-}$cells displayed limited tumor formation in mouse intracranial xenografts. Importantly, 23 out of 24 primary GBMs analyzed contained a subpopulation of SSEA-1 ${ }^{+}$cells. These results together suggest that SSEA-1 is a useful marker for both normal NSCs and the large majority of GBMs.

\section{SIDE POPULATIONS}

Another common means to identify CSCs in multiple cancer types is by staining with Hoechst 33342 dye. The concept behind Hoechst 33342 staining is that all cells take up the dye, but stem cells export the dye, due to high expression levels of ATP-binding cassette (ABC) transporters, such as MDR1 (ABCB1) and BCRP (ABCG2) [Hadnagy et al., 2006]. Hoechst-treated cancer cells can be analyzed with flow cytometry, to measure fluorescence at both red and blue emission wavelengths. A small (typically <2\%), double-negative group of cells can be selected, and this population is termed the side population (SP). This method has been effective in isolating populations enriched for tumorigenic CSCs in the rat glioma 
cell line C6 [Kondo et al., 2004] and human glioma cell lines U373MG and U87MG [Patrawala et al., 2005].

However, even with the successful enrichment of CSCs by Hoechst 33342 exclusion, disagreement about the specificity of Hoechst 33342 continues. Stem cells persist in the non-SP fraction of both the hematopoietic system [Morita et al., 2006] and mammary glands [Stingl et al., 2006]. In addition, CD133 ${ }^{+}$are found in both the SP and non-SP fractions of medulloblastoma line, DAOY, with a four-fold higher expression in the non-SP [Srivastava and Nalbantoglu, 2008]. Once again, the progress in the field is limited by inconsistency and the lack of a definitive means to isolate a pure population of GBM CSCs.

Despite the presence of CSCs in GBMs and success in isolating populations with stem cell characteristics by Hoechst 33342 staining and CD133 expression, the lack of purity of the isolated CSCs and inconsistencies among different tumor samples is a persistent problem for the discovery of CSC-targeted therapies for GBMs. The field has recognized the caveats of using a single CSC marker, such as CD133, and new work has been published on markers SSEA-1 and A2B5; however, there is currently not an accepted set of surface markers that can be used to successfully isolate a pure and inclusive population of CSCs. Indeed, the heterogeneity of GBMs may make it difficult to use a single set of markers to identify and purify CSCs in all GBM tumors.

\section{THE OBSTACLE OF THERAPY-RESISTANT CSCS}

Due to the infiltrative nature of GBMs, it is impossible to surgically remove all of the malignant cells. It is clear that most GBMs possess a population of cells that are resistant to treatment, as demonstrated by the local recurrence of tumors after surgical resection, radiation and chemotherapy. The proposal that a CSC is a prerequisite for tumor formation suggests that chemoresistant and radioresistant CSCs are the cause of GBM recurrence.

Two independent labs have published data supporting the chemoresistance of glioma CSCs and one describing radioresistance of glioma CSCs. Liu et al. found that CD133 ${ }^{+}$cells were resistant to chemotherapeutic agents, temozolomide, carboplatin, VP16, and Taxol compared to the $\mathrm{CD}_{133^{-}}$cells sorted from the same primary glioma cultures [Liu et al., 2006]. It has also been demonstrated that glioma cells resistant to 1,3-bis(2-chloroethyl)-1nitrosourea (BCNU) expressed high levels of CD133+ [Kang and Kang, 2007]. These BCNU-resistant cells were also capable of multilineage differentiation and formed intracranial tumors when injected into immunocompromised mice. In addition, ionizing radiation treatment enriched for the $\mathrm{CD} 133^{+}$population of human glioma cultures derived from xenografts and freshly isolated GBM samples [Bao et al., 2006]. By colony formation assays, it was further demonstrated that sorted $\mathrm{CD} 133^{+}$populations were more resistant to ionizing radiation than the corresponding $\mathrm{CD} 133^{-}$populations. This data supports the theory that CSCs are resistant to current glioma therapies; however, due to recent data suggesting that CD133 does not identify all CSCs in glioma cultures, experiments using additional markers are needed.

The resistance of CSCs to therapy may be due to their stem cell characteristics. Despite their high proliferative capacity, normal stem cells can assume a quiescent state that is regulated by the stem cell niche. Cells that are not actively proliferating undergo reduced chemotherapy- and radiation-induced DNA damage. Although there is limited research confirming that glioma CSCs exist in a quiescent state, it is a commonly cited mechanism for therapy resistance in many tumor types [Mellor et al., 2005; Scopelliti et al., 2009]. Another feature that normal stem cells and CSCs share is the expression of drug efflux pumps. Adenosine triphosphate-binding cassette (ABC) pumps, ABCG2 and P-glycoprotein are expressed on glioma CSCs and can efflux the fluorescent Hoechst 33342 dye as well as 
chemotherepuetic agents [ $\mathrm{Lu}$ and Shervington, 2008]. CSCs also express an array of proteins that promote survival after treatments. Genes involved in drug resistance, such as BCRP1 and MGMT, and anti-apoptotic genes, such as FLIP, BCL-2 and BCL-XL, were upregulated in $\mathrm{CD}_{133^{+}}$glioma cells [Liu et al., 2006]. In addition, DNA checkpoint responses were preferentially activated in the $\mathrm{CD} 133^{+}$population after ionizing radiation [Bao et al., 2006]. Activating phosphorylation of Rad15, ATM, Chk1 and Chk2 were significantly higher in $\mathrm{CD}_{133^{+}}$populations when compared to their autologous $\mathrm{CD} 133^{-}$ populations, suggesting that $\mathrm{CD} 133^{+} \mathrm{CSCs}$ are radioresistant due, in part, to enhanced DNA repair. These features make CSCs and pathways related to stem cell function key targets for the development of future treatments against GBMs.

\section{A PROMISING FUTURE FOR THERAPIES TARGETING CANCER STEM CELLS NOTCH}

The CSC model proposes that signaling pathways associated with stem cells could be targeted to enhance therapy. The Notch signaling pathway is an important regulator in normal development, adult stem cell maintenance, and tumorigenesis in multiple organs, including the brain [Koch and Radtke, 2007]. There are four mammalian Notch receptors (Notch1-4) and five ligands in the Delta and Jagged families. Well-known targets of Notch signaling include members of the Hairy enhancer of split (Hes) and Hes-related repressor protein (HERP) families [Iso et al., 2003], cyclin D [Ronchini and Capobianco, 2001], and c-myc [Sharma et al., 2006]. Notch receptors, their ligands, and the downstream targets Hes 1 and Hes2 are commonly overexpressed in glioma cell lines and primary GBM samples [Kanamori et al., 2007; Shih and Holland, 2006].

In addition to the involvement of Notch in stem cell functions and its deregulation in GBMs, it is a promising target for directed therapy since Notch can be inhibited through multiple stages of Notch signaling [Rizzo et al., 2008]. The most common method of Notch inhibition in basic research, as well as in current Phase I and Phase II clinical trials, is via small molecule inhibitors of $\gamma$-secretase. When $\gamma$-secretase inhibitors (GSIs) are utilized, the Notch receptor is not cleaved and remains bound to the cellular membrane. This halts the Notch signaling pathway, because the intracellular domain fails to translocate into the nucleus. GSIs can cause cytotoxicity in the gastrointestinal tract [Barten et al., 2006]; however, intermittent treatment schedules appear to diminish these side effects [Rizzo et al., 2008]. Inhibition of Notch signaling through GSI or shRNAs against Notch1, both suppressed the growth of glioma cells and increased differentiation [Kanamori et al., 2007]. Correspondingly, increased Notch signaling enhanced glioma cell survival [Purow et al., 2005].

An important, hypothetical advantage of Notch inhibition in glioma therapy is the ability to directly target the CSC population. Recent studies have begun to demonstrate that inhibiting the Notch signaling pathway directly affects the CSC phenotype of GBMs. Notch signaling was found to directly activate the transcription of the stem cell marker, nestin [Shih and Holland, 2006]. Expression of nestin in a murine Kras glioma model was demonstrated to correlate specifically with Notch activation. Likewise, knockdown of Notch by shRNAs or GSIs decreased the expression of stem cell markers nestin and CD133 [Jeon et al., 2008]. Loss of Notch signaling also decreased neurosphere formation. These results suggest that an active Notch pathway is required to maintain the CSC population of GBMs and may be a promising target for therapy, although further research is necessary to determine the mechanism by which loss of Notch either decreases stem cell functions or depletes the CSC pool. 


\section{HEDGEHOG}

Another stem cell pathway vital to normal brain development and NSC survival is the Hedgehog (Hh) pathway [Ahn and Joyner, 2005; Wechsler-Reya and Scott, 1999]. Hh is activated when ligands bind to the Patched receptor. Ligand binding activates the membrane protein Smoothened and its target, Gli1, which was first identified in human glioma [Kinzler et al., 1987]. The Hh pathway has been demonstrated to play a role in tumorigenesis and is activated in primary GBMs and glioma cell lines. Treatment of neurosphere cultures with a Smoothened inhibitor, cyclopamine, inhibited sphere formation, and enhanced radiation treatment [Bar et al., 2007] and temozolomide chemotherapy [Clement et al., 2007]. Cyclopamine treatment also depleted the number of nestin ${ }^{+}$cells, CD $133^{+}$cells, and the Hoechst 33342 SP population [Bar et al., 2007]. In vivo treatment of intracranial neurosphere xenografts with cyclopamine reduced tumor volume [Clement et al., 2007], suggesting that inhibiting Hh increases the efficiency of current GBM therapies by targeting a CSC population.

\section{FINAL CONCLUSIONS AND FUTURE DIRECTIONS}

When judging a theory, it is natural to ask whether the basic tenets of the theory stand up and whether the theory offers new ideas and approaches. The CSC model proposes that a minority of cells with stem cell-like properties initiates tumor formation. Recently, it was found that single melanoma cells can initiate tumors, and as many as $25 \%$ of tumor cells are competent to form tumors [Quintana et al., 2008]. This is a higher percentage than was originally envisioned, but oncogene activation and loss of tumor suppressors can increase the fraction of stem cell-like cells [Li et al., 2009; Schindler et al., 2009]. The stem cell-like nature of these cells is demonstrated by differentiation of CSCs in a variety of tumors. In addition, genes associated with maintenance of stem cells, such as BMI1, play an important role in GBM neurosphere cultures [Abdouh et al., 2009]. However, a definitive demonstration of the stem cell-like character of these cells requires purification of the CSCs. For solid tumors, there are disagreements about the specificity of stem cell markers. We hope that the new technique of growing adherent CSCs will facilitate these experiments. Finally, the CSC model continues to generate new and productive ideas. We have already discussed potential therapies directed against stem cell-associated signaling pathways. Recently, an antibody-based therapy directed against acute myeloid leukemia CSCs was shown to enhance survival in a mouse model [Jin et al., 2009]. Although additional mechanisms (e.g., clonal selection) likely contribute to tumor cell heterogeneity, the CSC model continues to help us analyze human tumors and elucidate new therapies.

\section{Acknowledgments}

Grant sponsor: NIH grant NS021716

\section{References}

Abdouh M, Facchino S, Chatoo W, Balasingam V, Ferreira J, Bernier G. BMI1 sustains human glioblastoma multiforme stem cell renewal. J Neurosci. 2009; 29:8884-96. [PubMed: 19605626]

Ahmed S. The culture of neural stem cells. J Cell Biochem. 2009; 106:1-6. [PubMed: 19021147]

Ahn S, Joyner AL. In vivo analysis of quiescent adult neural stem cells responding to Sonic hedgehog. Nature. 2005; 437:894-7. [PubMed: 16208373]

Al-Hajj M, Wicha MS, Benito-Hernandez A, Morrison SJ, Clarke MF. Prospective identification of tumorigenic breast cancer cells. Proc Natl Acad Sci U S A. 2003; 100:3983-8. [PubMed: 12629218]

Altman J. Autoradiographic investigation of cell proliferation in the brains of rats and cats. Anat Rec. 1963; 145:573-91. [PubMed: 14012334] 
Altman J, Das GD. Autoradiographic and histological evidence of postnatal hippocampal neurogenesis in rats. J Comp Neurol. 1965; 124:319-35. [PubMed: 5861717]

Bao S, Wu Q, McLendon RE, Hao Y, Shi Q, Hjelmeland AB, Dewhirst MW, Bigner DD, Rich JN. Glioma stem cells promote radioresistance by preferential activation of the DNA damage response. Nature. 2006; 444:756-60. [PubMed: 17051156]

Bar EE, Chaudhry A, Lin A, Fan X, Schreck K, Matsui W, Piccirillo S, Vescovi AL, DiMeco F, Olivi A, Eberhart CG. Cyclopamine-mediated hedgehog pathway inhibition depletes stem-like cancer cells in glioblastoma. Stem Cells. 2007; 25:2524-33. [PubMed: 17628016]

Barraud P, Stott S, Mollgard K, Parmar M, Bjorklund A. In vitro characterization of a human neural progenitor cell coexpressing SSEA4 and CD133. J Neurosci Res. 2007; 85:250-9. [PubMed: 17131412]

Barten DM, Meredith JE Jr, Zaczek R, Houston JG, Albright CF. Gamma-secretase inhibitors for Alzheimer's disease: balancing efficacy and toxicity. Drugs R D. 2006; 7:87-97. [PubMed: 16542055]

Beier D, Hau P, Proescholdt M, Lohmeier A, Wischhusen J, Oefner PJ, Aigner L, Brawanski A, Bogdahn U, Beier CP. CD133(+) and CD133(-) glioblastoma-derived cancer stem cells show differential growth characteristics and molecular profiles. Cancer Res. 2007; 67:4010-5. [PubMed: 17483311]

Bidlingmaier S, Zhu X, Liu B. The utility and limitations of glycosylated human CD133 epitopes in defining cancer stem cells. J Mol Med. 2008; 86:1025-32. [PubMed: 18535813]

Bonnet D, Dick JE. Human acute myeloid leukemia is organized as a hierarchy that originates from a primitive hematopoietic cell. Nat Med. 1997; 3:730-7. [PubMed: 9212098]

Clement V, Sanchez P, de Tribolet N, Radovanovic I, Ruiz i Altaba A. HEDGEHOG-GLI1 signaling regulates human glioma growth, cancer stem cell self-renewal, and tumorigenicity. Curr Biol. 2007; 17:165-72. [PubMed: 17196391]

Corbeil D, Roper K, Hellwig A, Tavian M, Miraglia S, Watt SM, Simmons PJ, Peault B, Buck DW, Huttner WB. The human AC133 hematopoietic stem cell antigen is also expressed in epithelial cells and targeted to plasma membrane protrusions. J Biol Chem. 2000; 275:5512-20. [PubMed: 10681530]

Eyler CE, Rich JN. Survival of the fittest: cancer stem cells in therapeutic resistance and angiogenesis. J Clin Oncol. 2008; 26:2839-45. [PubMed: 18539962]

Florek M, Haase M, Marzesco AM, Freund D, Ehninger G, Huttner WB, Corbeil D. Prominin-1/ CD133, a neural and hematopoietic stem cell marker, is expressed in adult human differentiated cells and certain types of kidney cancer. Cell Tissue Res. 2005; 319:15-26. [PubMed: 15558321]

Green CL, Loken M, Buck D, Deeg HJ. Discordant expression of AC133 and AC141 in patients with myelodysplastic syndrome (MDS) and acute myelogeneous leukemia (AML). Leukemia. 2000; 14:770-2. [PubMed: 10764169]

Grey BR, Oates JE, Brown MD, Clarke NW. Cd133: a marker of transit amplification rather than stem cell phenotype in the prostate? BJU Int. 2009; 103:856-8. [PubMed: 19076138]

Hadnagy A, Gaboury L, Beaulieu R, Balicki D. SP analysis may be used to identify cancer stem cell populations. Exp Cell Res. 2006; 312:3701-10. [PubMed: 17046749]

Hemmati HD, Nakano I, Lazareff JA, Masterman-Smith M, Geschwind DH, Bronner-Fraser M, Kornblum HI. Cancerous stem cells can arise from pediatric brain tumors. Proc Natl Acad Sci U S A. 2003; 100:15178-83. [PubMed: 14645703]

Iso T, Kedes L, Hamamori Y. HES and HERP families: multiple effectors of the Notch signaling pathway. J Cell Physiol. 2003; 194:237-55. [PubMed: 12548545]

Jaksch M, Munera J, Bajpai R, Terskikh A, Oshima RG. Cell cycle-dependent variation of a CD133 epitope in human embryonic stem cell, colon cancer, and melanoma cell lines. Cancer Res. 2008; 68:7882-6. [PubMed: 18829544]

Jeon HM, Jin X, Lee JS, Oh SY, Sohn YW, Park HJ, Joo KM, Park WY, Nam DH, DePinho RA, Chin L, Kim H. Inhibitor of differentiation 4 drives brain tumor-initiating cell genesis through cyclin $\mathrm{E}$ and notch signaling. Genes Dev. 2008; 22:2028-33. [PubMed: 18676808]

Jin L, Lee EM, Ramshaw HS, Busfield SJ, Peoppl AG, Wilkinson L, Guthridge MA, Thomas D, Barry EF, Boyd A, Gearing DP, Vairo G, Lopez AF, Dick JE, Lock RB. Monoclonal antibody-mediated 
targeting of CD123, IL-3 receptor alpha chain, eliminates human acute myeloid leukemic stem cells. Cell Stem Cell. 2009; 5:31-42. [PubMed: 19570512]

Kanamori M, Kawaguchi T, Nigro JM, Feuerstein BG, Berger MS, Miele L, Pieper RO. Contribution of Notch signaling activation to human glioblastoma multiforme. J Neurosurg. 2007; 106:417-27. [PubMed: 17367064]

Kang MK, Kang SK. Tumorigenesis of chemotherapeutic drug-resistant cancer stem-like cells in brain glioma. Stem Cells Dev. 2007; 16:837-47. [PubMed: 17999604]

Kinzler KW, Bigner SH, Bigner DD, Trent JM, Law ML, O’Brien SJ, Wong AJ, Vogelstein B. Identification of an amplified, highly expressed gene in a human glioma. Science. 1987; 236:70-3. [PubMed: 3563490]

Koch U, Radtke F. Notch and cancer: a double-edged sword. Cell Mol Life Sci. 2007; 64:2746-62. [PubMed: 17687513]

Kondo T, Setoguchi T, Taga T. Persistence of a small subpopulation of cancer stem-like cells in the C6 glioma cell line. Proc Natl Acad Sci U S A. 2004; 101:781-6. [PubMed: 14711994]

Lee J, Kotliarova S, Kotliarov Y, Li A, Su Q, Donin NM, Pastorino S, Purow BW, Christopher N, Zhang W, Park JK, Fine HA. Tumor stem cells derived from glioblastomas cultured in bFGF and EGF more closely mirror the phenotype and genotype of primary tumors than do serum-cultured cell lines. Cancer Cell. 2006; 9:391-403. [PubMed: 16697959]

Lendahl U, Zimmerman LB, McKay RD. CNS stem cells express a new class of intermediate filament protein. Cell. 1990; 60:585-95. [PubMed: 1689217]

Li L, Dutra A, Pak E, Labrie JE 3rd, Gerstein RM, Pandolfi PP, Recht LD, Ross AH. EGFRvIII expression and PTEN loss synergistically induce chromosomal instability and glial tumors. Neuro Oncol. 2009; 11:9-21. [PubMed: 18812521]

Liu G, Yuan X, Zeng Z, Tunici P, Ng H, Abdulkadir IR, Lu L, Irvin D, Black KL, Yu JS. Analysis of gene expression and chemoresistance of CD133+ cancer stem cells in glioblastoma. Mol Cancer. 2006; 5:67. [PubMed: 17140455]

Lu C, Shervington A. Chemoresistance in gliomas. Mol Cell Biochem. 2008; 312:71-80. [PubMed: 18259841]

Mellor HR, Ferguson DJ, Callaghan R. A model of quiescent tumour microregions for evaluating multicellular resistance to chemotherapeutic drugs. Br J Cancer. 2005; 93:302-9. [PubMed: 16052217]

Miraglia S, Godfrey W, Yin AH, Atkins K, Warnke R, Holden JT, Bray RA, Waller EK, Buck DW. A novel five-transmembrane hematopoietic stem cell antigen: isolation, characterization, and molecular cloning. Blood. 1997; 90:5013-21. [PubMed: 9389721]

Morita Y, Ema H, Yamazaki S, Nakauchi H. Non-side-population hematopoietic stem cells in mouse bone marrow. Blood. 2006; 108:2850-6. [PubMed: 16804114]

Nunes MC, Roy NS, Keyoung HM, Goodman RR, McKhann G 2nd, Jiang L, Kang J, Nedergaard M, Goldman SA. Identification and isolation of multipotential neural progenitor cells from the subcortical white matter of the adult human brain. Nat Med. 2003; 9:439-47. [PubMed: 12627226]

O'Brien CA, Pollett A, Gallinger S, Dick JE. A human colon cancer cell capable of initiating tumour growth in immunodeficient mice. Nature. 2007; 445:106-10. [PubMed: 17122772]

Ogden AT, Waziri AE, Lochhead RA, Fusco D, Lopez K, Ellis JA, Kang J, Assanah M, McKhann GM, Sisti MB, McCormick PC, Canoll P, Bruce JN. Identification of A2B5+CD133- tumorinitiating cells in adult human gliomas. Neurosurgery. 2008; 62:505-14. discussion 514-5. [PubMed: 18382330]

Ostermann S, Csajka C, Buclin T, Leyvraz S, Lejeune F, Decosterd LA, Stupp R. Plasma and cerebrospinal fluid population pharmacokinetics of temozolomide in malignant glioma patients. Clin Cancer Res. 2004; 10:3728-36. [PubMed: 15173079]

Patrawala L, Calhoun T, Schneider-Broussard R, Zhou J, Claypool K, Tang DG. Side population is enriched in tumorigenic, stem-like cancer cells, whereas ABCG2+ and ABCG2- cancer cells are similarly tumorigenic. Cancer Res. 2005; 65:6207-19. [PubMed: 16024622]

Pollard SM, Yoshikawa K, Clarke ID, Danovi D, Stricker S, Russell R, Bayani J, Head R, Lee M, Bernstein M, Squire JA, Smith A, Dirks P. Glioma stem cell lines expanded in adherent culture 
have tumor-specific phenotypes and are suitable for chemical and genetic screens. Cell Stem Cell. 2009; 4:568-80. [PubMed: 19497285]

Pruszak J, Sonntag KC, Aung MH, Sanchez-Pernaute R, Isacson O. Markers and methods for cell sorting of human embryonic stem cell-derived neural cell populations. Stem Cells. 2007; 25:225768. [PubMed: 17588935]

Purow BW, Haque RM, Noel MW, Su Q, Burdick MJ, Lee J, Sundaresan T, Pastorino S, Park JK, Mikolaenko I, Maric D, Eberhart CG, Fine HA. Expression of Notch-1 and its ligands, Deltalike-1 and Jagged-1, is critical for glioma cell survival and proliferation. Cancer Res. 2005; 65:2353-63. [PubMed: 15781650]

Qiang L, Yang Y, Ma YJ, Chen FH, Zhang LB, Liu W, Qi Q, Lu N, Tao L, Wang XT, You QD, Guo $\mathrm{QL}$. Isolation and characterization of cancer stem like cells in human glioblastoma cell lines. Cancer Lett. 2009; 279:13-21. [PubMed: 19232461]

Quintana E, Shackleton M, Sabel MS, Fullen DR, Johnson TM, Morrison SJ. Efficient tumour formation by single human melanoma cells. Nature. 2008; 456:593-8. [PubMed: 19052619]

Reynolds BA, Weiss S. Generation of neurons and astrocytes from isolated cells of the adult mammalian central nervous system. Science. 1992; 255:1707-10. [PubMed: 1553558]

Reynolds BA, Weiss S. Clonal and population analyses demonstrate that an EGF-responsive mammalian embryonic CNS precursor is a stem cell. Dev Biol. 1996; 175:1-13. [PubMed: 8608856]

Rizzo P, Osipo C, Foreman K, Golde T, Osborne B, Miele L. Rational targeting of Notch signaling in cancer. Oncogene. 2008; 27:5124-31. [PubMed: 18758481]

Ronchini C, Capobianco AJ. Induction of cyclin D1 transcription and CDK2 activity by Notch(ic): implication for cell cycle disruption in transformation by Notch(ic). Mol Cell Biol. 2001; 21:5925-34. [PubMed: 11486031]

Schindler JW, Van Buren D, Foudi A, Krejci O, Qin J, Orkin SH, Hock H. TEL-AML1 corrupts hematopoietic stem cells to persist in the bone marrow and initiate leukemia. Cell Stem Cell. 2009; 5:43-53. [PubMed: 19570513]

Scopelliti A, Cammareri P, Catalano V, Saladino V, Todaro M, Stassi G. Therapeutic implications of Cancer Initiating Cells. Expert Opin Biol Ther. 2009; 9:1005-16. [PubMed: 19545218]

Sen A, Kallos MS, Behie LA. New tissue dissociation protocol for scaled-up production of neural stem cells in suspension bioreactors. Tissue Eng. 2004; 10:904-13. [PubMed: 15265308]

Sharma VM, Calvo JA, Draheim KM, Cunningham LA, Hermance N, Beverly L, Krishnamoorthy V, Bhasin M, Capobianco AJ, Kelliher MA. Notch1 contributes to mouse T-cell leukemia by directly inducing the expression of c-myc. Mol Cell Biol. 2006; 26:8022-31. [PubMed: 16954387]

Shih AH, Holland EC. Notch signaling enhances nestin expression in gliomas. Neoplasia. 2006; 8:1072-82. [PubMed: 17217625]

Singec I, Knoth R, Meyer RP, Maciaczyk J, Volk B, Nikkhah G, Frotscher M, Snyder EY. Defining the actual sensitivity and specificity of the neurosphere assay in stem cell biology. Nat Methods. 2006; 3:801-6. [PubMed: 16990812]

Singh SK, Clarke ID, Terasaki M, Bonn VE, Hawkins C, Squire J, Dirks PB. Identification of a cancer stem cell in human brain tumors. Cancer Res. 2003; 63:5821-8. [PubMed: 14522905]

Singh SK, Hawkins C, Clarke ID, Squire JA, Bayani J, Hide T, Henkelman RM, Cusimano MD, Dirks PB. Identification of human brain tumour initiating cells. Nature. 2004; 432:396-401. [PubMed: 15549107]

Son MJ, Woolard K, Nam DH, Lee J, Fine HA. SSEA-1 is an enrichment marker for tumor-initiating cells in human glioblastoma. Cell Stem Cell. 2009; 4:440-52. [PubMed: 19427293]

Srivastava VK, Nalbantoglu J. Flow cytometric characterization of the DAOY medulloblastoma cell line for the cancer stem-like phenotype. Cytometry A. 2008; 73:940-8. [PubMed: 18773455]

Stingl J, Eirew P, Ricketson I, Shackleton M, Vaillant F, Choi D, Li HI, Eaves CJ. Purification and unique properties of mammary epithelial stem cells. Nature. 2006; 439:993-7. [PubMed: 16395311]

Stupp R, Hegi ME, Mason WP, van den Bent MJ, Taphoorn MJ, Janzer RC, Ludwin SK, Allgeier A, Fisher B, Belanger K, Hau P, Brandes AA, Gijtenbeek J, Marosi C, Vecht CJ, Mokhtari K, Wesseling P, Villa S, Eisenhauer E, Gorlia T, Weller M, Lacombe D, Cairncross JG, Mirimanoff 
RO. Effects of radiotherapy with concomitant and adjuvant temozolomide versus radiotherapy alone on survival in glioblastoma in a randomised phase III study: 5-year analysis of the EORTCNCIC trial. Lancet Oncol. 2009

Stupp R, Mason WP, van den Bent MJ, Weller M, Fisher B, Taphoorn MJ, Belanger K, Brandes AA, Marosi C, Bogdahn U, Curschmann J, Janzer RC, Ludwin SK, Gorlia T, Allgeier A, Lacombe D, Cairncross JG, Eisenhauer E, Mirimanoff RO. Radiotherapy plus concomitant and adjuvant temozolomide for glioblastoma. N Engl J Med. 2005; 352:987-96. [PubMed: 15758009]

Tang DG, Patrawala L, Calhoun T, Bhatia B, Choy G, Schneider-Broussard R, Jeter C. Prostate cancer stem/progenitor cells: identification, characterization, and implications. Mol Carcinog. 2007; 46:1-14. [PubMed: 16921491]

Tchoghandjian A, Baeza N, Colin C, Cayre M, Metellus P, Beclin C, Ouafik L, Figarella-Branger D. A2B5 Cells from Human Glioblastoma have Cancer Stem Cell Properties. Brain Pathol. 2009

Uchida N, Buck DW, He D, Reitsma MJ, Masek M, Phan TV, Tsukamoto AS, Gage FH, Weissman IL. Direct isolation of human central nervous system stem cells. Proc Natl Acad Sci U S A. 2000; 97:14720-5. [PubMed: 11121071]

Wechsler-Reya RJ, Scott MP. Control of neuronal precursor proliferation in the cerebellum by Sonic Hedgehog. Neuron. 1999; 22:103-14. [PubMed: 10027293]

Woolard K, Fine HA. Glioma stem cells: better flat than round. Cell Stem Cell. 2009; 4:466-7. [PubMed: 19497271]

Zhang QB, Ji XY, Huang Q, Dong J, Zhu YD, Lan Q. Differentiation profile of brain tumor stem cells: a comparative study with neural stem cells. Cell Res. 2006; 16:909-15. [PubMed: 17088899] 


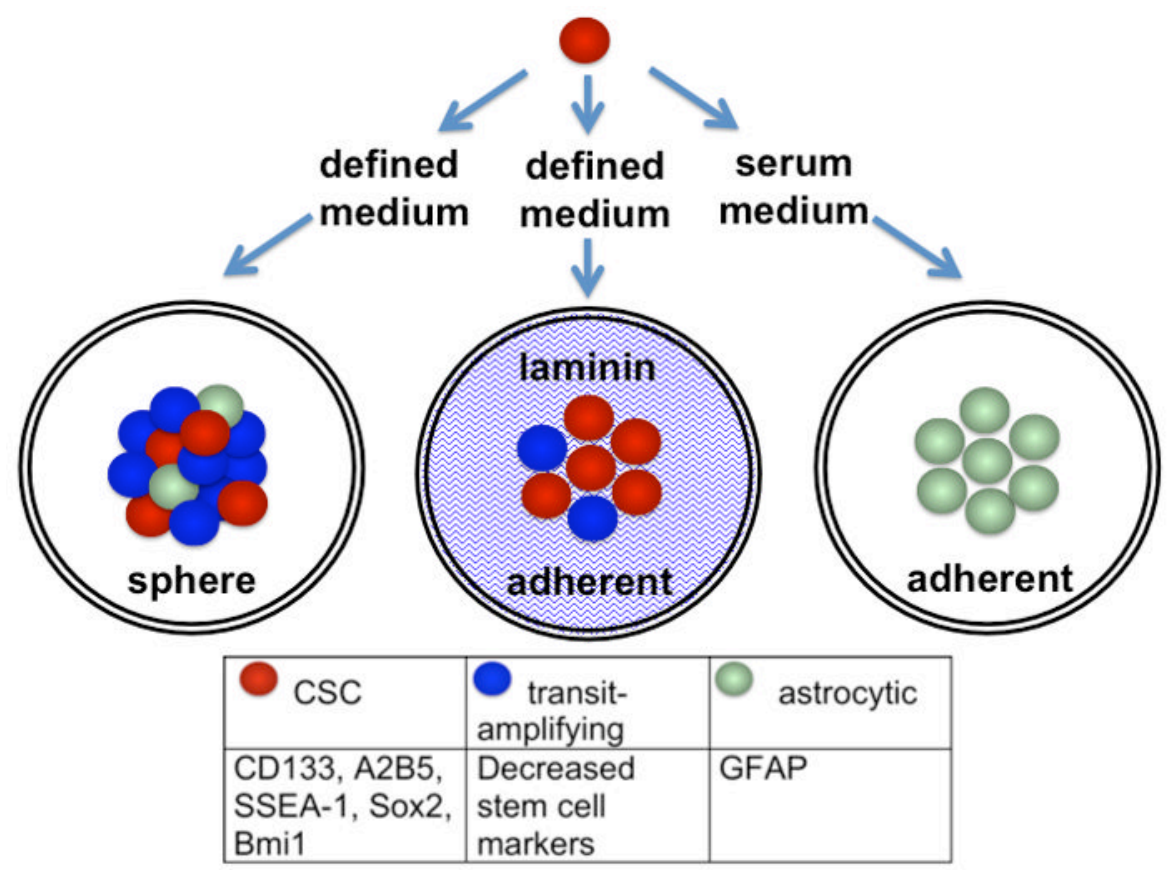

Fig. 1.

Proposed lineage for glioma CSCs. The CSCs (red) cultured in defined medium express stem cell markers, some of which are listed. CSCs may not express all of these markers and may vary from tumor to tumor. The CSCs differentiate to transit-amplifying cells.

Expression of stem cell markers is decreased in the transit-amplifying cells (blue), but there are no distinct markers that are upregulated in the transit-amplifying cells. As the spheres mature, a few of the transit-amplifying cells differentiate to astrocytic cells and, to a lesser degree, neuronal and oligodendrocytic markers (astrocytic cells = green). With the adherent laminin cell culture system, stem cell marker expression is enhanced, suggesting that the fraction of CSCs is increased. Also, there are almost no astrocytic cells. Treatment with serum rapidly and efficiently induces astrocytic differentiation. 
TABLE 1

Culture conditions strongly affect stem cell properties of glioblastoma cultures.

\begin{tabular}{|c|c|c|c|}
\hline & Medium with serum & Defined medium & $\begin{array}{c}\text { Laminin substratum with } \\
\text { defined medium }\end{array}$ \\
\hline Culture description & adherent & neurosphere & adherent \\
\hline Expression of stem cell markers & weak & strong & very strong \\
\hline Expression of differentiation markers & strong & weak & weak \\
\hline Tumors resulting from cultured cells & circumscribed & invasive & strong homology \\
\hline Gene expression profiles & weak homology to parent tumor & strong homology & $\begin{array}{c}\text { enriched for stem cells and } \\
\text { adherent }\end{array}$ \\
\hline Utility for screening CSC therapies & poor because few CSCs & poor because not adherent & \\
\hline
\end{tabular}

